\title{
Teachers Perceptions of the Leadership Behaviours of Primary School Head Teachers in Kenya
}

\author{
Kenneth Otieno* \\ Department of Educational Psychology, Masinde Muliro University of Science \& Technology, Kakamega, \\ Kenya \\ *Corresponding Author: Kenneth Otieno, Department of Educational Psychology, Masinde Muliro \\ University of Science \& Technology, Kakamega, Kenya
}

\begin{abstract}
In several public primary schools in Kenya, autocratic administration and supervision by head teachers appears to be the rule rather than the exception. Despite the emphasis of democracy in the modern world there are still too many administrators who are at least semi-dictators. They rely on "position power" instead of "people power," The structure of administration demands that the classroom teacher is directly answerable to the head of the institution who provides both guidance and supervision and determines the rate of promotion or the quality and speed of incentives. It is against this background that this study investigated theteachrs perception of the leadership behaviour patterns of primary school head teachers in Nyanza region. Kenya. The Ex-post facto research design was adopted in the study. Purposive and stratified random sampling techniques were used to select the study sample. The population of the study was 399 primary school teachers drawn from 32 primary schools and 8 Sub County Quality Assurance and Standards Officers (SQASOs) in Nyanza region. Data was collected by means of both structured and unstructured questionnaires and in-depth interviews. Data analysis was performed using the Statistical Package for the Social Sciences (SPSS) Version 16.0. The two tailed t-test and product-moment coefficient of correlation were run to establish the differences and relationships between the independent and dependent variables. The level of significance was set at 0.05. Content analysis of the written free responses was also carried out. It was established that most of the head teachers are high on initiating structure. In other words, the teachers do not perceive them as supportive and friendly. Teachers feel powerless, alienated and oppressed. They are largely dissatisfied with leadership. The female teachers perceived the head teachers as friendly, respectful warm and having mutual trust when dealing with the staff members unlike their male counterparts who saw their head teachers as dictatorial and not supportive. Older teachers perceived their leaders as higher in initiating structure than their younger counterparts. Novice teachers perceived their head teachers as supportive. They feel trust, admiration, loyalty and respect towards their head teachers. Teachers drawn from urban teachers perceived their head teachers autocratic and perhaps dictatorial unlike their rural counterparts while the single teachers perceived their leaders to be supportive than their married counterparts. It is recommended that individual head teachers, educational management personnel, planners and policy makers should have an informed understanding of leadership hence equip themselves with skills, abilities, behaviours, conflict management and resolution policies and strategies needed to encourage transformational rather than transactional leadership.
\end{abstract}

Key words: Consideration, initiating structure, leadership, leadership behaviour, novice

\section{INTRODUCTION}

In several public primary schools in Kenya, and Nyanza region in particular, autocratic administration and supervision by head teachers appears to be the rule rather than the exception. Despite the emphasis of democracy in the modern world there are still too many administrators who are at least semi-dictators. They rely on "position power" instead of "people power" (IPAR, 2008). The structure of administration demands that the classroom teacher is directly answerable to the head of the institution who provides both guidance and supervision and determines the rate of promotion or the quality and speed of incentives.

Consequently, with such leaders, teachers are reduced to mere artisans applying customarily the rule of the thumb techniques of survival which they have learned. Such administrative and supervisory procedures result in a lack of creativeness, a frustration of the need for independence, diminution of 
professional self-esteem, increased intrapersonal and interpersonal conflicts and hence the experience of high levels of burnout.

The focus of this study is on the leadership behaviour of primary school head teachers in Nyanza Region. The region has continued to post poor results since the inception of KCPE. In fact in the early 1980s, the province used to lead in the primary school examinations nationally.

For the purpose of this study, head teachers' leadership behaviour is described in terms of two broad behaviour patterns; one, concern with establishing an attitude of warmth and respect with teachers (concern for people or consideration) and two, organizing and defining the tasks of teachers in relation to goals (concern for tasks or initiating structure).

Basically, in the world of work today, there is a change in the concept of work. There is need for increased productivity. One does not work only for a living and thus one's work has to be viewed in the context of one's immediate environment and wider social needs. The work one does is an extension of oneself. Workers get motivated when their jobs afford them the opportunity to feel involved, and their needs and wants coincide with the organizational objectives. An individual works because the job provides him or her recognition, collegial interaction and a social life. Against this background is the head teacher who is seen as vital in shaping the fulfilment of human needs among those working under him or her. Therefore, leadership behaviour is likely to be an integral, yet understudied factor in the process that should be amenable to change in primary prevention efforts. As salient members of the environment, leaders definitely have a direct influence on the subordinate behaviour (Kozlowski \& Doherty, 1989). As such, head teachers may either increase stress (e.g. through using excessive control) or they can prevent stressors or facilitate coping with stress (through participatory management) (Misumi, 1985; Bass, 1990).

The head teacher and entire management of the school must therefore provide the teacher with not only a good physical environment and welfare amenities to keep him or her healthy but also other essential ingredients, which make the work itself human, rewarding and challenging. Taking cognizance of the fact that environments in which people work are diverse in context and content of human interactions, any intervention efforts require a research base.

Generally, studies (Tepper, 2000; Begley, 2004; Capel, 2005 \& Pines, 2006) on leader behaviour have brought out the following facts. First, Leadership is a function of groups, not individuals. The quality of relationship between the leader and follower is an important determinant of job satisfaction and team success. Second, Leadership styles can be differentiated as being either task-oriented or people oriented. Workers in organizations where there is a perfect blend of the two styles experience low levels of stress. Finally, The causal variables (things that leaders can modify), for example, organizational climate and structure and supervisory leadership moderate or mediate the levels of experienced stress among workers. It is against this background that a systematic study was needed to address this gap and shed light on the leadership behaviour patterns exhibited by primary school head teachers in Nyanza region, Kenya.

\section{RESEARCH METHODOLOGY}

The current study combined both quantitative and qualitative designs, which is described as methodological pluralism. Basically, primary school head teachers were selected for the study because they are charged with the responsibility of handling children during the formative stages of their development which is very important in shaping their future lives.

The research design adopted was Ex-post facto. This study design was selected mainly because it collects and describes the leadership behavior patterns exhibited by primary school teachers in Nyanza region, Kenya. Nyanza region was selected because of the poor results pupils in public primary schools have been posting since the inception of KCPE. In fact in the early 1980s, the province used to lead in the primary school examinations nationally hence, the need to investigate the head teachers' leadership behavior which might have impacted on the decline in academic standards at this level.

The population of the study was 3132 practicing primary school teachers drawn from 518 schools and 32 Sub County Quality Assurance and Standards Officers (SQASO's) spread across 32 Sub counties in Nyanza region. The study sample comprised 400 teachers, who were not head teachers, drawn from 
32 public primary schools spread across 16 Sub counties in Nyanza region and 8 SQASOs. Public primary school teachers were selected because they are all hired by the same employer, the Teachers Service Commission and so they work under the same terms and conditions of service.

Purposive sampling technique was used to identify common characteristics of the schools in the study. Thereafter, the stratified random sampling technique was used to select the study sample. The sampling unit was the school. The schools were classified into rural and urban categories. From each stratum, one school was chosen at random using the random number table. This technique of sampling ensured that each of the given type of school was represented in the study.

In this study the proportion of the target population with a certain characteristic is . 50 , the z-statistic is 1.87 , and the desired accuracy is at the 0.5 level, therefore, the sample size is calculated as follows.

$$
\begin{aligned}
\mathrm{n} & =\frac{2.0)^{2}(.50)}{(.5)^{2}} \\
& =400
\end{aligned}
$$

From the sampled thirty two primary schools, all the 400 teachers employed by the Teachers Service Commission (TSC) completed the questionnaires. However, one teacher did not return the questionnaire hence final study sample comprised 399 teachers and 8 SQASO's who accepted to complete the questionnaires.

To collect data in this research, self-report questionnaires and an interview schedule were used. Two questionnaires were used to collect data in this research. These were the Teacher Background Questionnaire (TBQ)) and the Leader Behaviour Questionnaire (LBQ) which also provided an opportunity for the respondents to give free responses. This helped in validating responses from the respondents.

The teachers had an opportunity to write anonymously. The tools were self-administered, that is, the respondents were allowed to complete the instruments themselves, but within a designated time. Finally, the interview schedule for the SQASOs was used to collect data. All the research tools were piloted to ascertain their validity and reliability in the Kenyan situation. After collecting the questionnaire sheets, the following were done: editing, coding (every respondent was given an identifier number), categorization of variables (grouping together items measuring the same concept), keying data, interpretation and analysis. Informed consent and maintaining confidentiality were the ethical issues considered in this study. The researcher accurately represented what the respondents reported without biases.

Data analysis was mainly quantitative and less qualitative. The analysis of qualitative data involved immersion, categorization, phenomenological reduction and interpretation. To analyze quantitative data, different methods were used. First and foremost, frequency distribution tables were generated from data collected. Histograms were generated from the frequency distribution tables. These two methods of data presentation assisted in data interpretation and analysis.

After scoring the three questionnaires, the data was coded and data files prepared for computer analysis. The analysis was performed using the Statistical Package for the Social Sciences (SPSS) Version 16.0. The level of significance was set at 0.05 . Content analysis of the written free responses of the respondents was also carried out. The two tailed t-test was used to determine the difference between the independent and dependent variables. On the other hand, the product-moment coefficient of correlation was used to establish the relationships between the independent and dependent variables.

\section{RESULTS AND DISCUSSION}

The study further sought to establish the differences between leadership behaviour, and the demographic variables. Analyses were conducted for each of the naturally occurring groups (gender, age, experience, locale and marital status) and calculated in relation to the Leadership Behaviour Questionnaire (LBQ). 


\subsection{Analysis was carried to Test the Following Null Hypothesis.}

$\mathrm{H}_{\mathrm{O} 2}$ : There is no significant difference between the head teachers' leadership behaviour and demographic factors among primary school teachers in Nyanza region.

\subsection{Distribution of Teachers by Gender}

Table 1 shows the distribution of male and female teachers in the sample population.

Table1. Gender of the Respondents

\begin{tabular}{|c|c|c|}
\hline Gender & Frequency & \% \\
\hline Female & 230 & 58 \\
\hline Male & 169 & 42 \\
\hline Total & $\mathbf{3 9 9}$ & $\mathbf{1 0 0}$ \\
\hline
\end{tabular}

Overall, most $(58 \%)$ of the respondents in the sample were females teachers. Male teachers only accounted for $42 \%$ of the whole sample. This is a good example of the actual distribution of female and male teachers in Kenya. It appears that females have a more positive disposition towards the teaching profession than their male counterparts who seem reluctant to join the profession. Wanjiru (2007) believes women are more sociable, empathic and nurturing than men. Besides, they have better communication skills which are essential for the teaching profession.

Table 2 contains the means and $\mathrm{t}$-values of male as well as female teachers on variables tested.

Table2. Differences between Male and Female Teachers on Leadership Behaviour Dimensions

\begin{tabular}{|l|l|l|l|l|l|l|}
\hline \multicolumn{3}{|c|}{$\begin{array}{c}\text { Male } \\
(\mathrm{N}=169)\end{array}$} & \multicolumn{4}{c|}{$\begin{array}{c}\text { Female } \\
(\mathrm{N}=230)\end{array}$} \\
\hline Variables & Mean & Std Deviation & Mean & Std Deviation & t- value & $\mathrm{P}$ \\
\hline C & 52.93 & 13.694 & 54.49 & 12.942 & $-1.16^{* *}$ & 0.247 \\
\hline IS & 33.93 & 7.911 & 33.23 & 8.471 & $-.35^{* *}$ & 0.727 \\
\hline & & & & & & \\
\hline
\end{tabular}

$\mathrm{P} *<0.05 \quad \mathrm{P} * *<0.001$

Overall, most (58\%) of the respondents in the sample were females teachers. Male teachers only accounted for $42 \%$ of the whole sample. This is a good example of the actual distribution of female and male teachers in Kenya. It appears that females have a more positive disposition towards the teaching profession than their male counterparts who seem reluctant to join the profession. Wanjiru (2007) believes women are more sociable, empathic and nurturing than men. Besides, they have better communication skills which are essential for the teaching profession.

Table 3 contains the means and $\mathrm{t}$-values of male as well as female teachers on variables tested.

Table3. Differences between Male and Female Teachers on Leadership Behaviour Dimensions

\begin{tabular}{|l|l|l|l|l|l|l|}
\hline \multicolumn{3}{|c|}{$\begin{array}{c}\text { Male } \\
(\mathrm{N}=169)\end{array}$} & \multicolumn{5}{c|}{$\begin{array}{c}\text { Female } \\
(\mathrm{N}=230)\end{array}$} \\
\hline Variables & Mean & Std Deviation & Mean & Std Deviation & t- value & $\mathrm{P}$ \\
\hline $\mathrm{C}$ & 52.93 & 13.694 & 54.49 & 12.942 & $-1.16^{* *}$ & 0.247 \\
\hline IS & 33.93 & 7.911 & 33.23 & 8.471 & $-.35^{* *}$ & 0.727 \\
\hline \multicolumn{2}{|l|}{} & & & & & \\
\hline
\end{tabular}

Significant differences were also found in respect of Consideration. The mean values were 52.93 and 54.49 for male and female teachers respectively, with a t-value of -.16 which was significant at 0.01 levels. The female teachers perceived the head teachers as friendly, respectful warm and having mutual trust when dealing with the staff members unlike their male counterparts who saw their head teachers as dictatorial and not supportive. Female teachers conceive of the head teachers as having a strong set of internal values. This finding is consistent with that of Sosik and Godshalk (2002) who reported that female teachers appreciated their leaders unlike their male colleagues.

The t-values show significant difference between male and female teachers on Initiating Structure. The mean values were 33.93 and 33.23 for male and female teachers respectively, with a t-value of - 
.35 which was significant at 0.01 levels. The male teachers perceived their head teachers as high in initiating structure.

Summing up the results on sex wise analysis, the trend shows that female teachers perceive their head teachers as very supportive and friendly unlike their male counterparts.

\subsection{Distribution of Teachers by Age}

Table 4 provides the age ranges of the sample population.

Table4. Age of the Respondents

\begin{tabular}{|l|l|l|}
\hline Age Group & Frequency & \% \\
\hline Below 21 Years & 0 & 0 \\
\hline $21-30$ Years & 149 & 37 \\
\hline $31-40$ Years & 128 & 32 \\
\hline Over 40 Years & 122 & 31 \\
\hline Total & $\mathbf{3 9 9}$ & $\mathbf{1 0 0}$ \\
\hline
\end{tabular}

The data shows that 37 per cent of the teachers belonged to the $21-30$ years age group. Those within the $31-40$ years age group accounted for 32 per cent of the total sample. Teachers with forty years accounted for 31 per cent of the total study sample. Teachers with over 30 years accounted for 63 per cent of the total sample. This implies that most of the schools had older and perhaps mature teachers.

The t-values entered in Table 5 show that there is a significant difference between younger and older teachers in respect of consideration and initiating structure at 0.01 levels.

Table5. Differences between Younger and Older Teachers on Leadership Behaviour Dimensions

\begin{tabular}{|l|l|l|l|l|l|l|}
\hline \multicolumn{3}{|c|}{$\begin{array}{c}\text { Younger } \\
(\mathrm{N}=149)\end{array}$} & \multicolumn{5}{c|}{$\begin{array}{c}\text { Older } \\
(\mathrm{n}=250)\end{array}$} \\
\hline Variable & Mean & Std Dev & Mean & Std Dev & t- value & P \\
\hline C & 58.46 & 14.164 & 51.06 & 11.905 & $5.35^{*}$ & 0.000 \\
\hline IS & 37.06 & 7.183 & 37.34 & 8.321 & $5.76^{*}$ & 0.000 \\
\hline
\end{tabular}

$\mathrm{P}^{*}<0.05 \quad \mathrm{P} * *<0.01$

Significant differences were also found in respect of Consideration at 0.05 levels.

Younger teachers perceived their head teachers as friendly and respectful unlike their older counterparts. Younger teachers believe that head teachers motivate members to act in ways that support the greater good rather than self interest. The mean values for the younger and older teachers are 58.46 and 51.06 respectively with a t-value of 5.35.

However, older teachers perceived their leaders as higher in initiating structure than their younger counterparts. The mean values for younger and older teachers with respect to Initiating Structure are 37.06 and 37.34 respectively with t-value of 5.76. Similar findings were reported by Susie and Knobloch (2002) with reference to Initiating Structure but inconsistent results were reported with regard to Consideration where the found that older teachers perceived their head teachers to be more friendly. This could probably be due to the fact that they had developed better coping strategies in dealing with conflicts unlike their younger counterparts.

\subsection{Distribution of Teachers by Experience}

Information on the distribution of teachers in terms of years of teaching experience is shown in Table 6.

Table6. Years of Teaching Experience

\begin{tabular}{|c|c|c|}
\hline Years of Teaching Experience & Frequency & \% \\
\hline Less than 1 Year & 21 & 5 \\
\hline $1-5$ Years & 112 & 28 \\
\hline $6-10$ Years & 67 & 17 \\
\hline $11-15$ Years & 114 & 29 \\
\hline Total & $\mathbf{3 9 9}$ & $\mathbf{1 0 0}$ \\
\hline
\end{tabular}


The results show that 28 per cent of the teachers had between $1-5$ years of teaching experience. Those with fifteen or less years of teaching experience accounted for 71 per cent of the total sample. On the other hand, those with over fifteen years of teaching experience accounted for 29 per cent of the total sample. This shows that most of the teachers in the total sample had relatively fewer years of teaching experience.

Teaching experience was studied under two sub-groups; novice and experienced teachers. Table 7 shows the means and t-values between the two groups in respect of leadership behaviour.

Table7. Differences between Novice and Experienced Teachers on Leader Behaviour Dimensions

\begin{tabular}{|l|l|l|l|l|l|l|}
\hline \multicolumn{3}{|c|}{$\begin{array}{c}\text { Novice } \\
\text { (N=209) }\end{array}$} & \multicolumn{5}{c|}{$\begin{array}{c}\text { Experienced } \\
(\mathrm{N}=190)\end{array}$} \\
\hline Variable & Mean & Std Dev & Mean & Std Dev & t- value & P \\
\hline C & 56.50 & 13.486 & 50.88 & 12.414 & $4.33^{* *}$ & 0.000 \\
\hline IS & 35.52 & 7.616 & 32.55 & 8.611 & $3.66^{* *}$ & 0.000 \\
\hline
\end{tabular}

$\mathrm{P}^{*}<0.05 \quad \mathrm{P} * *<0.01$

Significant differences were found between for novice and experienced teachers in respect of Consideration and Initiating Structure at 0.01 levels. The mean values are 56.50 and 50.88 for novice and experienced teachers respectively on the Consideration scale with a t-value of 4.33 . This means that novice teachers perceive their head teachers as supportive. They feel trust, admiration, loyalty and respect towards their head teachers. The findings support that of Susie and Knobloch (2002) who reported that experienced teachers perceived their head teachers to be less supportive.

Generally, it is important to note that most teachers usually begin their first teaching assignment filled with enthusiasm, energy, ready to invest the time and energy necessary for success. They find the work meaningful and gain a sense of accomplishment from interacting with pupils and watching them learn. Passionate about their work, they plan to make a positive difference in the lives of learners.

However, passionate and dedicated teachers are most at risk of experiencing occupational tedium. When their zeal and hard work are not rewarded, disillusionment prevails. Enthusiasm is replaced by despair. Their light grows dimmer, and they spiral towards experiencing occupational tedium. The occupational tedium process is complete when energy turns to exhaustion, involvement turns to detachment, and the sense of accomplishment becomes one of self doubt, cynicism and bitterness.

Essentially, as professionals dedicated to high expectation for themselves and their pupils, teachers may develop guilt feelings about the inability to cope with the complexes of modern life and demands of society resulting in a sense of low personal and professional growth. Also, the low status accorded to teaching and few of opportunities for advancement contribute to lowering teacher motivation levels. The finding supports that of Mulloch (1985) who reported that teachers with less experience are more prone to burnout unlike their experienced colleagues.

\subsection{Distribution of Teachers by Locale}

Table 8 shows the distribution of teachers by locale.

Table8. Distribution of Teachers by Locale

\begin{tabular}{|c|c|c|}
\hline Location & Frequency & \% \\
\hline Urban & 290 & 73 \\
\hline Rural & 109 & 27 \\
\hline Total & $\mathbf{3 9 9}$ & $\mathbf{1 0 0}$ \\
\hline
\end{tabular}

Data presented in Table 8 shows that 73 per cent of the respondents were drawn from the urban centres. Only 27 per cent of the total teachers sampled were from rural areas. From this distribution we can conclude that most teachers prefer working in urban areas. This is probably due to the fact that the urban areas have better amenities when compared with the rural areas. These may include better equipped hospitals, libraries, recreation and internet facilities which may not be easily available in rural areas.

The t-values entered in Table 9 show that there are significant differences between rural and urban teachers on the measures of leadership behaviour at 0.01 levels. 
Table9. Differences between Urban and Rural Teachers on Leadership Behaviour Dimensions

\begin{tabular}{|l|l|l|l|l|l|l|}
\hline \multicolumn{3}{|c|}{$\begin{array}{c}\text { Urban } \\
(\mathrm{N}=290)\end{array}$} & \multicolumn{5}{c|}{$\begin{array}{c}\text { Rural } \\
(\mathrm{N}=109)\end{array}$} \\
\hline Variables & Mean & Std Dev & Mean & Std Dev & t- value & P \\
\hline C & 53.18 & 13.220 & 55.45 & 13.350 & $-1.52^{* *}$ & 0.129 \\
\hline IS & 33.39 & 8.430 & 32.94 & 7.408 & $-2.78^{* *}$ & 0.006 \\
\hline
\end{tabular}

$\mathrm{P}^{* *}<0.01$

Significant differences were obtained in respect of Consideration and Initiating Structure at 0.01 levels. The t-value for Consideration is -1.52 which is significant at 0.01 levels. The mean values for Consideration are 55.45 and 53.18 for rural and urban teachers with a t-value of -1.52 . This shows that rural teachers' see their head teachers as high in consideration.

The mean values for Initiating Structure for rural and urban teachers are 33.39 and 32.94 with a tvalue of -2.78 . This shows that urban teachers perceive their head teachers autocratic and perhaps dictatorial unlike their rural counterparts. Rural teachers believe that their head teachers define objectives that members value the most and support them in accomplishing these objectives.

These findings are in tandem with those of Farber (1985) who reported that whereas teachers in the rural setting perceive their head teachers as less autocratic, unlike their urban counterparts, they experience higher levels of role ambiguity. On the other hand, their urban colleagues experience higher levels of role conflict.

\subsection{Distribution of Teachers by Marital Status}

Table 10 shows the distribution of teachers by their marital status.

Table10. Distribution of Teachers by Marital Status

\begin{tabular}{|l|l|l|}
\hline Marital Status & Frequency & \% \\
\hline Married & 327 & 82 \\
\hline Single & 61 & 15 \\
\hline Separated /Divorced & 6 & 2 \\
\hline Widowed & 5 & 1 \\
\hline Total & $\mathbf{3 9 9}$ & $\mathbf{1 0 0}$ \\
\hline
\end{tabular}

From Table 10, it is evident that most (82\%) of the teachers were married while 15 per cent of the respondents were single. Also, 2 per cent of the respondents were either separated or divorced and a paltry 1 per cent was widowed. From the results, it is clear that most teachers preferred marital and family lifestyles. It is basically important for teachers to maintain a balance between their personal and professional lifestyles (Skovholt, 2001). Having a supportive spouse and family provides the teacher with basic social support system. The situation may be grim for those who have either lost their spouses or are separated or divorced given the stresses that accompany such situations. Since teachers experience a lot of stress while on duty, a safe haven and secure base outside school is helpful. This can be in relationships with co-workers, supervisors, and supportive marital partners.

The t-values entered in Table 11 show that there exist significant differences between married and single teachers in respect of leadership behaviour at 0.01 levels.

Table11. Differences between Married and Single Teachers on Leader Behaviour Dimensions

\begin{tabular}{|l|l|l|l|l|l|l|}
\hline \multicolumn{3}{|c|}{$\begin{array}{l}\text { Married } \\
(\mathrm{N}=327)\end{array}$} & \multicolumn{5}{c|}{$\begin{array}{l}\text { Single } \\
(\mathrm{N}=72)\end{array}$} \\
\hline Variable & Mean & Std Dev & Mean & Std Dev & t- value & P \\
\hline C & 53.52 & 12.944 & 55.52 & 14.463 & $-1.04^{* *}$ & 0.303 \\
\hline IS & 33.70 & 8.161 & 36.70 & 8.035 & $-2.26^{* *}$ & 0.024 \\
\hline & & & & & & \\
\hline
\end{tabular}

$\mathrm{P} *<0.05 \quad \mathrm{P} * *<0.01$

Significant differences were obtained in respect of Consideration and Initiating Structure at 0.01 levels. The mean values for married and single teachers are 53.52 and 55.52 with a t-value of -1.04 . This implies that single teachers perceived their leaders to be supportive than their married counterparts. They perceive their head teachers as leaders who share information, delegate authority and keep open channels of communication with teachers. Besides, they tell teachers how essential 
their performance is, how confident they are with them and, how exceptional the teachers are. The mean values for married and single teachers are 36.70 and 36.20 with a t-value of -2.26 . This implies that married teachers perceived their head teachers to be less supportive. The findings are consistent with that of Shapiro and Corey (2008) who equally reported that teachers who were married perceived their head teachers as distant and indifferent. This could be due to the fact that married teachers have multiple roles which tend to overwhelm them.

Support by the head teacher plays a major role in reducing job stress and subsequent occupational tedium. Teachers who feel supported by their head teachers are less likely to experience occupational tedium. When support is not present, teachers feel that the head teacher is not on the 'same side' with them. They believe that the head teacher's only interest is in protecting a personal image and position rather than improving conditions for teachers and pupils. When then the head teacher cannot be trusted for support, teachers only work for the sake of it to avoid conflict.

\subsection{Distribution of Test Scores for the Leadership Behaviour Questionnaire}

To establish the leadership behaviour mainly exhibited by primary school head teachers in Nyanza, the distribution of test scores were established. The mean scores and the standard deviations of covariates were obtained and are presented in Table 1.

Table12. Characteristics of the Score Distribution $(N=399)$

\begin{tabular}{|c|c|c|}
\hline Variable & Score Distribution & Standard Deviation \\
\hline Consideration & 33.83 & 13.27 \\
\hline Initiating Structure & 34.10 & 8.230 \\
\hline
\end{tabular}

Table 12 shows the most important characteristics of the score distributions. The nature of leadership behaviour as perceived by the teachers was obtained by tabulating the average means and standard deviation for the two sub-scales. The mean and standard deviations for Consideration was $(\mathrm{M}=33.83$, $\mathrm{SD}=13.271)$ and Initiating Structure $(\mathrm{M}=34.10, \mathrm{SD}=8.230)$. From this result, it is evident that most of the head teachers are high on initiating structure.

Basically, head teachers who employ autocratic methods of management do not work harmoniously with their staff members. When a teacher perceives the head teacher as commanding and not giving them opportunity to participate in decision making, the teacher is likely to treats the pupils in derogatory ways and becomes more cynical towards them.

Leader consideration involves demonstrating concern and respect for subordinates, showing appreciation and support, and looking out for subordinates' welfare (Bass, 1990). With this type of behaviour, the leader-subordinate relations are one of mutual trust and two-way communication. Initiating structure, on the other hand, is oriented toward facilitating goal attainment. It involves the extent to which the leader initiates, organizes, and defines his/her role and the roles of subordinates, structuring the work to be completed and how it is to be completed. These behaviours pertain to how leaders behave towards subordinates in the group in general, rather than specific dyad-level relationships.

Consideration focuses on the charismatic and affective elements of leadership, and it is concerned with values, ethics, emotions, standards, and long-term goals (Northouse, 2004). It stresses the need to assess followers' motives, satisfy their needs, and treat them as human beings. Consideration leadership relies on the strong influence of visionary, charismatic leaders who move followers to accomplish objectives above and beyond what is usually expected. Siegrist (1999) states that if leadership is vital to the schools, preparation of those leaders is very serious business indeed, and graduate programmes must move beyond the training of efficient managers to the preparation of visionary, moral, and considerate leaders.

One key attribute of most considerate leaders is charisma. Weber (cited in Gillian, 2007) provided the most well-known definition of "charisma" as a special personality characteristic that gives a person superhuman or exceptional powers, is reserved for a few, is of divine origin, and results in the head teacher being treated as a leader. Charismatic head teachers act in unique ways that have specific transformational effects on their followers. They have a strong desire to influence teachers, being selfconfident, and having a strong sense of their own moral values. The results of successful charismatic leadership include teachers' trust in the head teacher's ideology, a similarity in belief systems among 
the stakeholders, acceptance of the head teacher, expression of warmth, obedience, and identification, emotional involvement with goals, and stakeholder confidence in goal achievement.

According to Northouse (2004), individuals who exhibit consideration leadership behaviours often have a strong set of internal values and ideals, and they are effective at motivating followers to act in ways that support the greater good rather than their own self-interests.

From the foregoing discussion, it is evident that considerate head teachers motivate their workers to do more than was thought possible. Setting high expectations and informing the teachers of the importance of the reaching those goals allows staff to focus on overall goals for the group and the school, and it also supports them in developing awareness of their personal needs and goals.

Although initiating structure leadership can be quite effective, it "does not involve a leader's commitment toward follower's personal development, nor does it involve a strong emotional attachment to the leader" (Jung \& Avolio, 2000, p. 951). The initiating structure head teacher is more of a manager than a leader, and is effective in crisis situations where there is a short-term resolution. In contrast, Avolio and Bass (2002) aver that "consideration leadership is more effective than initiating structure leadership in generating the extra effort, commitment, and satisfaction of those led" (p. 1).

Avolio and Bass (2002) have also noted that no one specific leadership style is appropriate for all situations; each situation may require a different style. "Each leader has a profile that includes some or both of these consideration and initiating structure behaviours. The better leaders practice both styles, and the best leaders are high in consideration than initiating structure" (p. viii).

\section{CONCLuSion}

From the foregoing discussion, the following conclusions are made. First and foremost, Most of the teachers in Nyanza region perceive their teachers to be high in initiating structure. In other words, the teachers do not perceive them as supportive and warm. Teachers feel powerless, alienated and oppressed. Traditional, rigid bureaucratically administered schools result in low teacher commitment and job dissatisfaction, Flexible schools that use collaborative problem solving strategies, which promote greater teacher affiliation with the school raises teacher morale. In the more flexible schools, teachers believe they can contribute to positive school change and that their ideas will be sought after and used. Second, consideration leadership is more effective than initiating structure leadership in generating extra effort, commitment, and satisfaction of employees. Last but not least, no one specific leadership style is appropriate for all situations; each situation requires a different style. In fact, the better leaders practice both styles but the best are high in consideration than in initiating structure.

Globally, it appears that traditional autocratic leadership paradigm is disintegrating, and in order to face the challenges of the modern age, head teachers in Kenya need to take an honest, extensive inventory of not only their external actions, but also of their internal intentions and motivations. The more they can develop a meta-awareness of their leadership behaviours, the more they can work to change or improve those elements of leadership that seem deficient, the more they can inspire those they lead and hence minimize incidences of conflict in school. In other words, they need to look after both their inner and their outer worlds as they strive to explore, validate, and cultivate the myriad qualities of an authentically successful transformational or consideration leader.

\section{Recommendations}

In terms of leadership behaviour, the principal strategy is to replace authority based management with participative management as a means to improve school effectiveness. Providing teachers with a significant role in school decision making is a key element in empowerment in that teachers gain the opportunity to increase control over their work environment.

Head teachers also need to be equipped with skills on conflict management and resolution. They should adopt functional conflict management strategies which move the school from stagnation to generation; it simulates and energizes. Ideas and issues are often clarified and as a result, productivity is increased, creative problem solving is exhibited and the incidences of stress are minimized.

Through the Kenya Primary Schools Head teachers Association (KEPSHA) seminars and workshops should be organized so that head teachers can share idea on how to effectively manage their schools. 
From such interactions the head teachers should also be equipped with strategies on conflict management and resolution.

The government through the Ministry of Education has a vital role to play in organizing in-service courses for head teachers on school management, facilitated by qualified and competent educationalists during the school holidays. Currently, the Kenya Education Management Institute (KEMI) organizes such courses through cost sharing basis.

The government should ensure that the school management committees are empowered and involved in the administration of schools. This will enable them guide the head teachers on leadership matters and also boost teacher morale. The Teachers Service Commission (TSC) should ensure that the professional ethics guide is periodically revised. This will ensure that it incorporates the modern trends in school matters.

Finally, as a suggestion for further research, this study may be replicated with different set of population such as private school.

\section{Acknowledgement}

Masinde Muliro University of Science and Technology

\section{REFERENCES}

[1] Avolio, B. J. \& Bass, B. M. (2002). "Developing potential across a full range of leaderships: cases on transactional and transformational leadership." Mahwah, NJ: Lawrence Erlbaum Associates.

[2] Bass, B.M. (1990). Bass \& Stodgill's handbook of leadership: Theory, research, \&management applications. New York: Free Press.

[3] Begley, D., (2004), "Tedium among special education administrators." A Paper presented to the Annual Convention of the Council for Exceptional Children. Houston, Texas. Berkeley Planning Associates.

[4] Bogler, R. (2001). "The influence of leadership style on teacher job satisfaction." Educational Administration Quarterly, 37(5), 662-683.

[5] Capel, S. A., (2005). "The Incidences of and influences on stress and tedium in cardiovascular disease: A cross-sectional study of a random sample of the cardiovascular health." Conclusions and Thoughts for a Future Agenda. Vol. 15/1. care units. Nurs Res. Mar-Apri; 33(2):97-101.

[6] Corey, G., Corey, M. \& Callanan, P. (2003). Issues and ethics in the helping professions. (6 $6^{\text {th }}$ edn.). New York: Brooks/ Cole.

[7] Crowther, F. (2002). 'Big change questions: Is the role of the principal in creating school improvement over-rated?", Journal of Educational Change, vol. 3, pp. 167-173.

[8] Farber, B.A. (1985). Stress and burnout in the human service profession. New York: Pergaman Press.

[9] Geijsel, F. Sleegers, P., Leithwood, K., \& Jantzi, D. (2001). “Transformational leadership effects on teachers' commitment and effort toward school reform. 'Journal of Educational Administration, 41(3), 228-256.

[10] Gillian, J.J. (2007). "An exploratory study of the prevalence and nature of burnout among public primary and secondary qualified school teachers in Santa Lucia." Unpublished MA Thesis. Trinity Western University.

[11] IPAR (2008). "Radical Reforms for Kenya's Education Sector. Implementing Policies Responsive to Vision 2030." Policy View Issue 4. An occasional publication of the Institute of Policy Analysis and Research (IPAR). Retrieved on August $9^{\text {th }}, 2008$ from http://www.ipar.or.ke

[12] Jung, D.I. and Avolio, B.J. (2000). "Opening the black box: An experimental investigation of the mediating effects of trust and value congruence on transformational and transactional leadership." Journal of Organizational Behaviour, 21, 949-964.

[13] Kozlowski, S., \& Doherty, M. (1989). "Integration of climate and leadership: Examination of a neglected issue.' Journal of Applied Psychology, 74, 546-553.

[14] Leith wood, K., Begley, P., and Cousins, J. (1992). Developing expert leadership for future schools. London: The Falmer Press.

[15] Levin, B. \& Riffel, J.A. (1997). School and the changing world: struggling towards the future. London Falmer.

[16] Misumi, J. (1985). The behavioural science of leadership: An interdisciplinary Japanese research programme. Ann Arbor, MI: University of Michigan Press.

[17] Northouse, P.G. (2004). Leadership Theory and Practice (3rd Ed).Sage, Sage Publications. 
[18] Pines, A. (2006). “Burnout.” In L. Goldberger \& S. Breznitz (Eds.). Handbook of Stress (2 ${ }^{\text {nd }}$ Ed.; pp. 386403). New York, New York: The Free Press.

[19] Plank, D. \& Boyd, W.D. (1994). "Antipolitics, education and institutional choice: The light of democracy.' American Educational Research Journal, 31(2), /263-281.

[20] Shapiro, A. \& Correy, L.M.K. (2008). "Marital status and the social well-being: are the married always better off?' Social Indicators Research, 88, 329-346.

[21] Siegrist, J. (1999). "Adverse health effects of reward in balance at work: Theory, empirical support and implication for prevention.” In C.L. Cooper (Ed.), Theories of Organizational Stress (pp.190-204). Oxford: Oxford University Press.

[22] Skovholt, F. (2001). The resilient practitioner. Burnout prevention and self care strategies for counsellors, therapists, teachers and health professionals. Boston: Allyn and Bacon.

[23] Sosik, J. J., \& Godshalk, V. M. (2000). “Leadership styles, mentoring functions received, and job-related stress: A conceptual model and preliminary study.' 'Journal of Organizational Behavior, 21 (4), 365-390.

[24] Tepper, B. J. (2000). “Consequences of abusive supervision.' Academy of Management Journal, 43, 178190.

[25] Wanjiru, G.C., (2006). "Role of supervision in the management of counselor burnout." Unpublished PhD thesis submitted to University of South Africa.

Citation: Kenneth Otieno. "Teachers Perceptions of the Leadership Behaviours of Primary School Head Teachers in Kenya" International Journal of Managerial Studies and Research (IJMSR), vol 8, no. 7, 2020, pp. 100-110. doi: http:// dx.doi.org/10.20431/2349-0349.0807013.

Copyright: (C) 2020 Authors. This is an open-access article distributed under the terms of the Creative Commons Attribution License, which permits unrestricted use, distribution, and reproduction in any medium, provided the original author and source are credited. 